\title{
A novel LC-MS method development and validation for the determination of phenyl vinyl sulfone in eletriptan hydrobromide
}

\author{
Indhu Priya Mabbu $^{{ }^{*}}$ D, G. Sumathi ${ }^{2}$ and N. Devanna ${ }^{1}$
}

\begin{abstract}
Background: The aim of the present method is to develop and validate a specific, sensitive, precise, and accurate liquid chromatography-mass spectrometry (LC-MS) method for the estimation of the phenyl vinyl sulfone in the eletriptan hydrobromide. The effective separation of the phenyl vinyl sulfone was achieved by the Symmetry C18 $(50 \times 4.6 \mathrm{~mm}, 3.5 \mu \mathrm{m})$ column and a mobile phase composition of $0.1 \% \mathrm{v} / \mathrm{v}$ ammonia buffer to methanol $(5: 95 \mathrm{v} / \mathrm{v})$, using $0.45 \mathrm{ml} / \mathrm{min}$ flow rate and $20 \mu \mathrm{l}$ of injection volume, with methanol used as diluent. The phenyl vinyl sulfone was monitored on atomic pressure chemical ionization mode mass spectrometer with positive polarity mode.

Results: The retention time of phenyl vinyl sulfone was found at $2.13 \mathrm{~min}$. The limit of detection (LOD) and limit of quantification (LOQ) were observed at $1.43 \mathrm{ppm}$ and $4.77 \mathrm{ppm}$ concentration respectively; the linear range was found in the concentration ranges from 4.77 to $27.00 \mathrm{ppm}$ with regression coefficient of 0.9990 and accuracy in the range of $97.50-102.10 \%$. The percentage relative standard deviation (\% RSD) for six replicates said to be injections were less than $10 \%$.
\end{abstract}

Conclusion: The proposed method was validated successfully as per ICH guidelines. Hence, this is employed for the determination of phenyl vinyl sulfone in the eletriptan hydrobromide.

Keywords: Phenyl vinyl sulfone, Eletriptan, Atomic pressure chemical ionization, Limit of detection

\section{Background}

Eletriptan is a selective serotonin receptor agonist, which especially blocks the $5-\mathrm{HT}_{1 \mathrm{~B} / 1 \mathrm{D}}$ receptors [1-3]. It was used as the first line drug of choice for the severe headache and migraine. Chemically, eletriptan is 5-[2-(benzenesulfonyl)ethyl]-3-\{[(2R)-1-methylpyrrolidin-2-

yl]methyl\}-1H-indole [4]. Phenyl vinyl sulfone is used as building blocks in the synthesis of a number of organic substances, involved in polymerization reactions. Chemically, it is ethenyl sulfonyl benzene [5]. Chemical structures of eletriptan and phenyl vinyl sulfone were shown in Fig. 1.

\footnotetext{
* Correspondence: priyamabbu245@gmail.com

'Department of Chemistry, Jawaharlal Nehru Technological University

Anantapur, Anantapur, Andhra Pradesh 515002, India

Full list of author information is available at the end of the article
}

The phenyl vinyl sulfone is used in the synthesis of eletriptan; hence, phenyl vinyl sulfone can be considered as process impurity [6]. As per ICH Q3 guidelines, the acceptance limit for the presence of unknown and known impurities in the drug substance is 0.10 to $0.15 \%$ [7]. In general, various analytical methods like high-performance liquid chromatography (HPLC), Fourier-transform infrared spectroscopy, and liquid chromatography-mass spectrometry (LC-MS) are used for identification, characterization, and quantification of impurities present in the drug substance and drug product. Based on literature review, few analytical methods like high-performance liquid chromatography methods and LC-MS methods were available for separation of forced degradation impurities of eletriptan [8-11]. But as of now, no LC-MS method has been reported for the determination of phenyl

\section{Springer Open}

(-) The Author(s). 2021 Open Access This article is licensed under a Creative Commons Attribution 4.0 International License, which permits use, sharing, adaptation, distribution and reproduction in any medium or format, as long as you give appropriate credit to the original author(s) and the source, provide a link to the Creative Commons licence, and indicate if changes were made. The images or other third party material in this article are included in the article's Creative Commons licence, unless indicated otherwise in a credit line to the material. If material is not included in the article's Creative Commons licence and your intended use is not permitted by statutory regulation or exceeds the permitted use, you will need to obtain permission directly from the copyright holder. To view a copy of this licence, visit http://creativecommons.org/licenses/by/4.0/. 
<smiles>CN1CCC[C@H]1Cc1c[nH]c2ccc(CCS(=O)(=O)c3ccccc3)cc12</smiles>

Eletriptan

Molecular weight: $382.52 \mathrm{~g} / \mathrm{mol}$ Molecular formula: $\mathrm{C}_{22} \mathrm{H}_{20} \mathrm{~N}_{2} \mathrm{O}_{2} \mathrm{~S}$

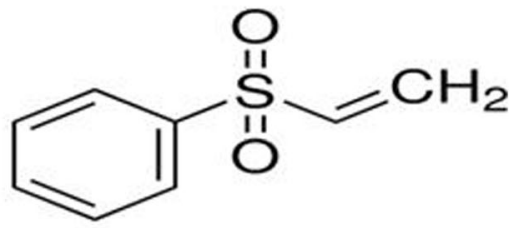

Phenyl vinyl sulfone

Molecular Weight: $168.21 \mathrm{~g} / \mathrm{mol}$

Molecular Formula: C8H8O2S

Fig. 1 Chemical structures of eletriptan and phenyl vinyl sulfone

vinyl sulfone in eletriptan hydrobromide. Hence, we aimed to develop a LC-MS method for the determination of phenyl vinyl sulfone in eletriptan hydrobromide.

\section{Methods}

The phenyl vinyl sulfone reference standard (claim 99.32\%) was procured from Fortune Pharma, Hyderabad, as a gift sample. All HPLC grade solvents were obtained from the Merck India Limited, Mumbai, India. All the solvents and solutions used were filtered through millipore $(0.25 \mu \mathrm{m})$ filters.

\section{Optimized LC-MS method conditions}

The Waters LC-MS with auto sampling system was used to perform the method. Separation of the phenyl vinyl sulfone was successfully achieved by the Symmetry $\mathrm{C} 18(50 \times 4.6 \mathrm{~mm}, 3.5 \mu \mathrm{m})$ column and a mobile phase composition of $0.1 \% \mathrm{v} / \mathrm{v}$ ammonia buffer to methanol $(5: 95 \mathrm{v} / \mathrm{v})$, using $0.45 \mathrm{ml} / \mathrm{min}$ flow rate and $20 \mu \mathrm{l}$ of injection volume, with methanol used as diluent. The temperature maintained in the auto sampler and column was $5{ }^{\circ} \mathrm{C}$ and ambient respectively. MS parameters were mentioned in the Table 1 .

\section{Preparation of phenyl vinyl sulfone standard stock solution (1000 ppm)}

Two hundred fifty milligrams of phenyl vinyl sulfone standard substance was weighed accurately and transferred into $10 \mathrm{ml}$ volumetric flask and diluted with diluent. The $0.4 \mathrm{ml}$ of above solution was further diluted to $10 \mathrm{ml}$ to get a concentration of $1000 \mathrm{ppm}$.

\section{Preparation of standard solution (18.0 ppm)}

$0.36 \mathrm{ml}$ of the standard stock solution was diluted to 20 $\mathrm{ml}$ to obtain a standard concentration of $18 \mathrm{ppm}$.

\section{Preparation of test solution}

The test solution accurately weighed about $100.00 \mathrm{mg}$ of the eletriptan test sample and was diluted to $10 \mathrm{ml}$ with diluent.

\section{Method validation}

System suitability test

The system suitability of the method was performed by injecting blank solution once and 100\% level standard solution of phenyl vinyl sulfone for six times into LCMS system. The system suitability was confirmed by assessing the \% RSD.

\section{Linearity}

The linearity of a method represents the direct proportional relationship between concentration and test result. It was conducted for the phenyl vinyl sulfone in the range of LOQ level $(4.767 \mathrm{ppm})$ to about $150 \%$ of limit $(27.00 \mathrm{ppm})$ by injecting each level of concentration two times and plotted a curve between

Table 1 MS parameters

\begin{tabular}{ll}
\hline lonization mode & $\mathrm{APCl}$ \\
Acquisition mode & $\mathrm{SIM}$ \\
Polarity mode & Positive \\
Ch1 & $169.14[\mathrm{M}+\mathrm{H}]^{+}$ \\
Light source temperature & $120^{\circ} \mathrm{C}$ \\
Heat block & $350^{\circ} \mathrm{C}$ \\
Cone gas flow & $50 \mathrm{~L} / \mathrm{Hr}$. \\
Desolvation gas flow & $950 \mathrm{~L} / \mathrm{Hr}$ \\
Capillary [KV] & $3.50[\mathrm{KV}]$ \\
Cone $[\mathrm{V}]$ & $25.00 \mathrm{~V}$ \\
Extractor $[\mathrm{V}]$ & $3.0 \mathrm{~V}$ \\
\hline
\end{tabular}



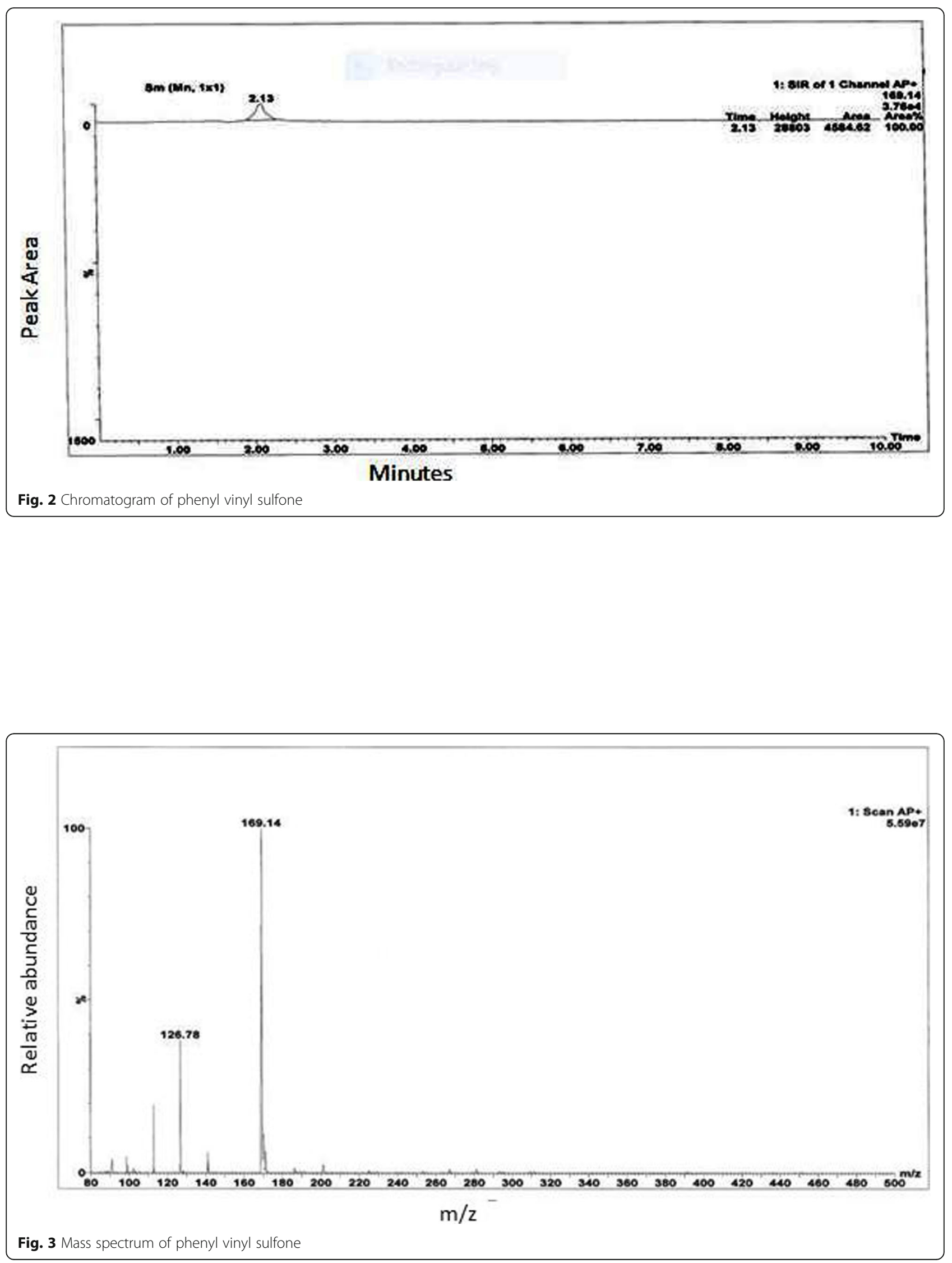
average peak area versus concentration in $\mathrm{ppm}$ to find out the regression coefficient value.

\section{Accuracy}

The accuracy of the method has been done by performing the recovery studies, at LOQ level, 50\%, $100 \%$, and $150 \%$ level. A known amount of phenyl vinyl sulfone spiked separately to pre-analyzed samples of the mentioned levels. Each spiked level was injected for three times into the LC-MS system and calculated the percent recovery of each level.

\section{Method precision}

The method precision was performed by spiking the sample with phenyl vinyl sulfone at $100 \%$ of the specified limit with respect to the sample concentration. Six homogenous replicates were injected and calculated the content of phenyl vinyl sulfone to determine the \% RSD.

\section{Intermediate precision}

The intermediate precision was performed by spiking the sample with phenyl vinyl sulfone at $100 \%$ of the specified limit with respect to the sample concentration in six preparations. The intermediate precision study was carried out on different days with different analysts. We calculated the content of phenyl vinyl sulfone in spiked preparations and determined the \% RSD.

\section{Sensitivity (LOD and LOQ)}

Limit of detection (LOD) and limit of quantification (LOQ) of the analytical method were determined by using signal to noise ratio. The LOD solution was prepared in such a way to obtain the $\mathrm{S} / \mathrm{N}$ ratio is about $3: 1$ to $5: 1$. Based on the concentration of LOD, the LOQ solution was prepared (3 times to LOD concentration) to obtain the signal to noise ratio of about $10: 1$ to $15: 1$.
Table 2 System suitability results of phenyl vinyl sulfone

\begin{tabular}{ll}
\hline Injection no. & Peak area of phenyl vinyl sulfone \\
\hline 1 & 4665.99 \\
2 & 4663.07 \\
3 & 4560.94 \\
4 & 4740.70 \\
5 & 4584.62 \\
6 & 4624.78 \\
Average & $\mathbf{4 6 4 0 . 0 2}$ \\
*\% RSD & $\mathbf{1 . 3 9}$ \\
\hline *\% RSD percentage relative standard deviation
\end{tabular}

\section{Results}

Initially, the solubility of the phenyl vinyl sulfone was checked in various solvents. It was found that phenyl vinyl sulfone was slightly soluble in methanol and water.

\section{Method optimization}

The optimized LC-MS method was achieved by using trial and error methods. After several trails, an efficient method was obtained by the Symmetry C18 $(50 \times 4.6$ $\mathrm{mm}, 3.5 \mu \mathrm{m})$ column and a mobile phase composition of $0.1 \% \mathrm{v} / \mathrm{v}$ ammonia buffer to methanol $(5: 95 \mathrm{v} / \mathrm{v})$, using $0.45 \mathrm{ml} / \mathrm{min}$ flow rate and $20 \mu \mathrm{l}$ of injection volume, with methanol used as diluent. The temperature maintained in the auto sampler and column was $5{ }^{\circ} \mathrm{C}$ and ambient respectively. The phenyl vinyl sulfone in the optimized chromatogram was eluted at $2.13 \mathrm{~min}$ (Fig. 2) and molecular ion and base peak at 169.14 in mass spectrum (Fig. 3).

\section{Method validation}

The developed method was validated as per Q2 specifications of the $\mathrm{ICH}$ guidelines.

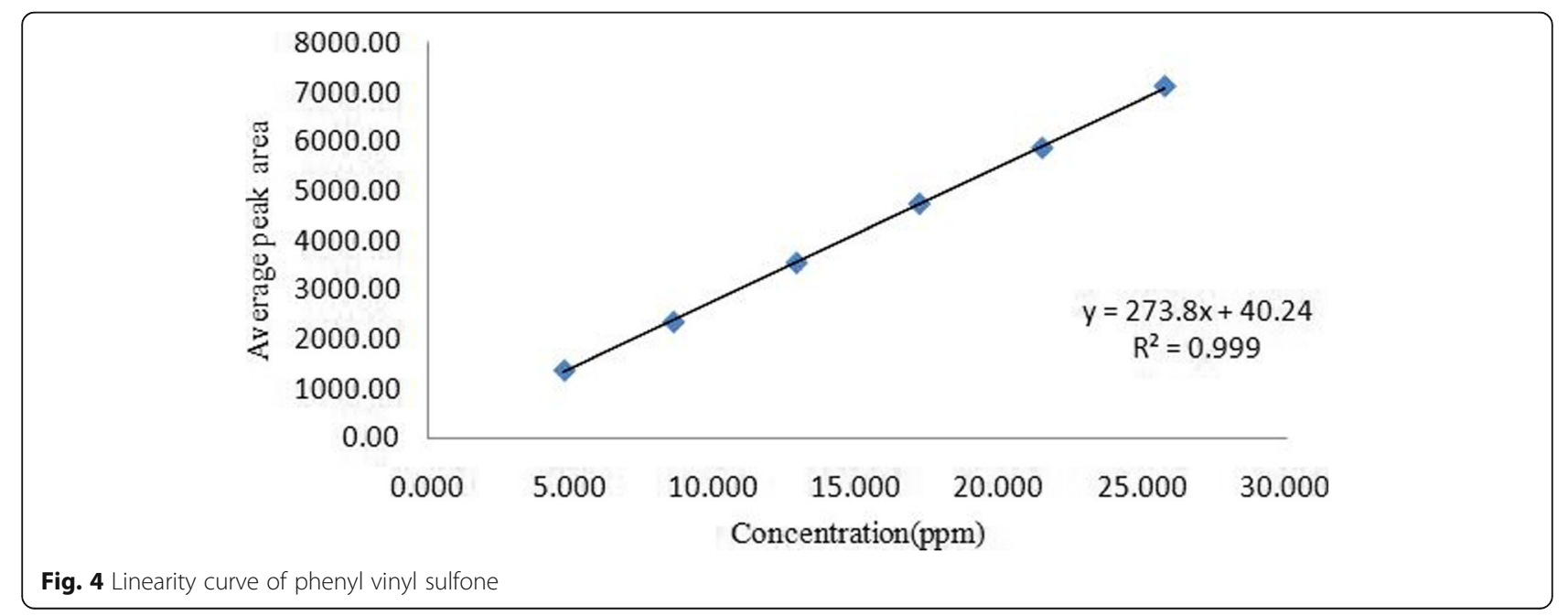


Table 3 Linearity for phenyl vinyl sulfone

\begin{tabular}{lll}
\hline Level & Concentration $(\mathbf{p p m})$ & Area of phenyl vinyl sulfone \\
\hline LOQ & 4.767 & 1380.85 \\
50 & 9.00 & 2358.16 \\
75 & 13.50 & 3555.80 \\
100 & 18.00 & 4747.76 \\
125 & 22.50 & 5878.87 \\
150 & 27.00 & 7121.44 \\
\multicolumn{2}{l}{ Regression coefficient $\left(\boldsymbol{R}^{2}\right)$} & $\mathbf{0 . 9 9 9 0}$ \\
\hline
\end{tabular}

$R^{2}$ value within the acceptance limit that is not less than 0.9 , not more than 1

\section{System suitability}

The system suitability of the developed method was confirmed by evaluating the typical system suitability parameters of the $100 \%$ level concentration including \% RSD. The results (Table 2) satisfied the acceptance criteria.

\section{Linearity}

The linearity of the present method was done for phenyl vinyl sulfone in the range of LOQ level to about $150 \%$ of limit. The regression coefficient $\left(R^{2}\right)$ value was calculated from the calibration curve, which was constructed by plotting between obtained peak area and concentrations.

$R^{2}$ value of the calibration curve was 0.9990 . The results are shown in Fig. 4 and Table 3 respectively.

\section{Accuracy}

The percentage recovery of phenyl vinyl sulfone from the different levels of spiked sample solutions was in the range of $97.50-102.10 \%$ (Table 4) which indicates that accuracy of the proposed method was very accurate and

Table 4 Accuracy results of phenyl vinyl sulfone

\begin{tabular}{llll}
\hline $\begin{array}{l}\text { Accuracy } \\
\text { levels }\end{array}$ & $\begin{array}{l}\text { No. of } \\
\text { preparations }\end{array}$ & $\begin{array}{l}\text { Peak area of } \\
\text { phenyl vinyl } \\
\text { sulfone }\end{array}$ & $\begin{array}{l}\text { \% recovery of } \\
\text { phenyl vinyl sulfone }\end{array}$ \\
\hline QL & 1 & 1380.02 & 101.00 \\
& 2 & 1346.10 & 99.00 \\
& 3 & 1383.94 & 102.10 \\
$50 \%$ & 1 & 2388.88 & 103.00 \\
& 2 & 2267.30 & 97.50 \\
& 3 & 2304.20 & 98.70 \\
$100 \%$ & 1 & 4220.62 & 91.00 \\
& 2 & 4218.18 & 91.50 \\
& 3 & 4350.34 & 93.90 \\
$150 \%$ & 1 & 6354.86 & 90.90 \\
& 2 & 6499.08 & 92.80 \\
& 3 & 6114.37 & 87.50 \\
\hline
\end{tabular}

QL quantitative limit the results were lied within the acceptance limits $( \pm$ $25 \%)$ of the ICH guidelines.

\section{Precision}

The \% RSD values for method precision and intermediate precision of the phenyl vinyl sulfone were found to 1.88 and 1.91 for the $100 \%$ level concentration (17.161 ppm) precision respectively (Table 5). The lower values $(\leq 10)$ of both precisions represents that the method has good precision.

\section{Sensitivity}

The LOD and LOQ of the phenyl vinyl sulfone were found to be $1.43 \mathrm{ppm}$ and $4.77 \mathrm{ppm}$, respectively, which indicates that the method has good sensitivity. Table 6 shows the LOD and LOQ results of the phenyl vinyl sulfone.

\section{Discussion}

As per extensive literature review, as of now, no analytical method has been reported for the estimation of phenyl vinyl sulfone in eletriptan hydrobromide. Among the various analytical techniques, the LC-MS method is a proficient and insightful technique to separate, identify, and quantify the impurities of the drug substance and drug product [8]. Few analytical methods were reported for the estimation of related substances and degradants of eletriptan hydrobromide [8-11]. During the synthesis of the eletriptan hydrobromide, polyvinyl sulfone has the possibility to exist as process impurity. The developed LC-MS method was highly effective to separate, identify, and quantify the polyvinyl sulfone. The current method has good sensitivity with a detection level of $1.43 \mathrm{ppm}$ of polyvinyl sulfone with high specificity. A simple solvent system of $0.1 \% \mathrm{v} / \mathrm{v}$ ammonia buffer to methanol $(5: 95 \mathrm{v} /$

Table 5 Summary of results for method precision and intermediate precision

\begin{tabular}{lll}
\hline $\begin{array}{l}\text { No. of } \\
\text { preparations }\end{array}$ & \multicolumn{2}{l}{ Peak area of phenyl vinyl sulfone (100\%level ) } \\
\cline { 2 - 3 } & Method precision & Intermediate precision \\
\hline 1 & 4220.62 & 4210.62 \\
2 & 4218.18 & 4218.18 \\
3 & 4350.34 & 4340.34 \\
4 & 4157.12 & 4137.12 \\
5 & 4183.75 & 4283.75 \\
6 & 4134.87 & 4134.87 \\
Average & 4210.81 & 4220.81 \\
Standard deviation & 76.15 & 80.93 \\
*\% RSD & 1.88 & 1.91 \\
\hline
\end{tabular}

*\% RSD percentage relative standard deviation 
Table 6 LOD and LOQ results of the phenyl vinyl sulfone

\begin{tabular}{lll}
\hline Parameter & Signal to noise ratio $(\mathbf{S} / \mathbf{N})$ & Concentration $(\mathbf{p p m})$ \\
\hline LOD & 3.71 & 1.43 \\
LOQ & 14.19 & 4.77 \\
\hline
\end{tabular}

v) represents the cost effectiveness of the method. Rapid analysis of eletriptan hydrobromide samples can be done for estimation of phenyl vinyl sulfone.

\section{Conclusion}

A specific and sensitive LC-MS method was developed for the determination of the content of the phenyl vinyl sulfone in eletriptan hydrobromide pure and pharmaceutical dosage form. The proposed method has very good sensitivity, accuracy, and specificity. Hence, this method has intended use in the process chemistry department and quality control department to identify and quantify the phenyl vinyl sulfone impurity in eletriptan hydrobromide.

\section{Abbreviations}

ICH: International Council for Harmonization; HPLC: High-performance liquid chromatography; RT: Retention time

\section{Acknowledgements}

The authors are also thankful to the Department of Chemistry, JNT

University, Ananthapur, India, for encouragement.

\section{Authors' contributions}

IM, SG, and DN contributed equally in the design of the work, acquisition and interpretation of data, and manuscript preparation. All authors have read and approved the manuscript.

\section{Funding}

It is self-financed; no funding was sponsored from any organization, funding agency, and non -profit research bodies.

Availability of data and materials

All data and material should be available upon request.

\section{Ethics approval and consent to participate}

No animal and human subjects were used in this study.

\section{Consent for publication}

Not applicable.

\section{Competing interests}

The authors declare that there is no conflict of interest.

\section{Author details}

${ }^{1}$ Department of Chemistry, Jawaharlal Nehru Technological University Anantapur, Anantapur, Andhra Pradesh 515002, India. ${ }^{2}$ Department of Chemistry, Anantha Lakshmi Institute of Technology and Sciences,

Anantapur, Andhra Pradesh 515002, India.

Received: 3 August 2020 Accepted: 29 December 2020

Published online: 14 January 2021

\section{References}

1. Derry S, Moore RA, Mcquay HJ (2010) Eletriptan for acute migraine headaches in adults. Cochrane Database Syst Rev 4

2. Sandrini G, Perrotta A, Nappi G (2006) Eletriptan: a review and new perspectives. Expert Rev Neurother 6:1413-1421
3. Takiya L, Piccininni LC, Kamath V (2006) Safety and efficacy of eletriptan in the treatment of acute migraine. Pharmacother J Hum Pharmacol Drug Ther 26:115-128

4. Pubchem, Eletriptan. Https://Pubchem.Ncbi.NIm.Nih.Gov/Compound/77993 (Accessed 24 Apr 2020).

5. Pubchem, Phenyl vinyl sulfone. Https://Pubchem.Ncbi.Nlm.Nih.Gov/ Compound/79664 (Accessed 24 Apr 2020).

6. Madasu SB, Vekariya NA, Kiran MN, Gupta B, Islam A, Douglas PS, Babu KR (2012) Synthesis of compounds related to the anti-migraine drug eletriptan hydrobromide. Beilstein J Org Chem 8:1400-1405

7. $\mathrm{Q} 3 a(R)$ Impurities in new drug substances, FDA. Https:/Www.Fda.Gov/ Regulatory-Information/Search-Fda-Guidance-Documents/Q3ar-ImpuritiesNew-Drug-Substances (Accessed 25 Apr 2020).

8. Singh PK, Dinda SC (2013) Development and validation of a stability indicating RP-HPLC method for determination of eletriptan in eletriptan hydrobromide orally disintegrating tablets. Int Res J Pharm 4:179-182

9. Jocić B, Zečević M, Živanović L, Protić A, Jadranin M, Vajs V (2009) Study of forced degradation behavior of eletriptan hydrobromide by LC and LC-MS and development of stability-indicating method. J Pharm Biomed Anal 50: 622-629

10. Rao PVSRM, Babu RK, Murthy CHVR, Acharyulu MLN (2016) Analytical application of E.B.T in spectrophotometric determination of eletriptan hydrobromide. Innovare J Sci 5:538-540

11. Rambabu CH, Venugopal V, Ramu G, Bikshan A (2012) An isocratic reverse phase HPLC method development for the determination of eletriptan hydrobromide in pure and pharmaceutical formulations. Int J Pharm Tech. Res 4:1504-1507

\section{Publisher's Note}

Springer Nature remains neutral with regard to jurisdictional claims in published maps and institutional affiliations.

\section{Submit your manuscript to a SpringerOpen ${ }^{\circ}$ journal and benefit from:}

- Convenient online submission

- Rigorous peer review

- Open access: articles freely available online

- High visibility within the field

- Retaining the copyright to your article

Submit your next manuscript at $\boldsymbol{\nabla}$ springeropen.com 